\title{
РОЗВИТОК МІЖНАРОДНОГО ТРАНЗИТНОГО ПОТЕНЦІАЛУ УКРАЇНИ
}

\author{
Д.т.н., Прокудін Г. С. \\ К.т.н., Чупайленко О. А. \\ К.т.н., Прокудін О. Г. \\ К.т.н., Дудник О. С. \\ Аспірант Пилипенко Ю. В.
}

Украӥна, м. Київ, Начіональний транспортний університет

DOI: https://doi.org/10.31435/rsglobal_ejits/31072019/6580

\section{ARTICLE INFO}

Received 11 May 2019

Accepted 10 July 2019

Published 31 July 2019

\section{KEYWORDS}

transit potential, mathematical model, transport system, optimization

\begin{abstract}
The model of complex transportations in the transport system is developed, which makes it possible to systematically approach the problem of optimization of international transport of non-homogeneous cargoes under the combined scheme of the use of various types of transport (automobile, water and railway) taking into account the whole spectrum of restrictions that exist in systems of this kind. The program complex for the optimization of international freight transport on the transport system of Ukraine and Western Europe, which is based on the model of management of multimodal freight traffic in international traffic, takes into account the throughput of transport nodes and communications of transport systems, and also can solve transport problems in the event of imbalance of volumes of transportation of heterogeneous cargoes.
\end{abstract}

Citation: Прокудін Г. С., Чупайленко О. А., Прокудін О. Г., Дудник О. С., Пилипенко Ю. В. (2019) Rozvytok Mizhnarodnoho Tranzytnoho Potentsialu Ukrainy. European Journal of Intelligent Transportation Systems. 1(2). doi: 10.31435/rsglobal_ejits/31072019/6580.

Copyright: (C) 2019 Прокудін Г. С., Чупайленко О. А., Прокудін О. Г., Дудник О. С., Пилипенко Ю. В. This is an open-access article distributed under the terms of the Creative Commons Attribution License (CC BY). The use, distribution or reproduction in other forums is permitted, provided the original author(s) or licensor are credited and that the original publication in this journal is cited, in accordance with accepted academic practice. No use, distribution or reproduction is permitted which does not comply with these terms.

Вступ. Головні резерви для розвитку міжнародних торгово-економічних відносин України - це транзитні можливості країни. Вигідне географічне положення України на перетині торгово-економічних напрямків Схід - Захід та Північ - Південь, а також наявність розвинутої транспортної інфраструктури, включаючи 22 тис. км залізничних шляхів, щільної мережі автомобільних доріг протяжністю 170 тис. км, наявності незамерзаючих морських торговельних портів, великої кількості суднохідних річок - це важлива основа формування потужної ефективної економіки України $[1,2]$.

Основу транзитного потенціалу України становить залізничний транспорт, яким перевозиться 82 \% усіх транзитних вантажів у країні. В основному це вантажі з Росії, Білорусі, Казахстану, Латвії, Литви, Естонії, які направляються в східно-європейські країни, а також через порти в інші країни світу [2].

Другою важливою складовою транзитного потенціалу України $є$ портовий комплекс, що включає 13 (до анексії Криму - 18) морських торговельних портів. Загалом технологічні потужності національної транспортної інфраструктури дозволяють щорічно перевозити залізницями, внутрішнім водним та автомобільним транспортом та переробляти в портах понад 110 млн. т. транзитних вантажів. Проте фактичні обсяги транзиту складають лише 41 млн. т., тобто наявний транзитний потенціал України (без трубопроводів) використовується менше ніж на 39 \% [2].

Загалом, потенціал України на міжнародному ринку транспортних послуг оцінюється експертами досить високо. За індексом логістичної ефективності (Logistics Performance Index), 
розрахованому Світовим банком, Україна зайняла 61 місце, що стало кращим показником серед усіх країн СНД [3].

Доцільно наголосити на тому, що Україна має усі передумови для створення потужної системи транзитних перевезень на міжнародному рівні і, як наслідок, збільшення обсягу транзиту вантажів. Так, наша держава має низку переваг перед іншими європейськими країнами, оскільки територією України проходять найкоротші сухопутні, морські та повітряні шляхи сполучення, що зв'язують Європу та країни Азіатсько-Тихоокеанського регіону. Міждержавний транзит українською територією - це великий, але досі нереалізований національний ресурс.

У перспективі транспортна мережа України все тісніше інтегруватиметься у високорозвинену європейську транспортну систему. Зокрема, передбачається будівництво транс'європейської автомагістралі Київ - Мадрид. Важливе значення для вантажних перевезень мають “міжнародні транспортні коридори", яких територією України проходить чотири, а саме: панєвропейський № 3 (Німеччина-Польща-Україна), панєвропейський № 5 (Італія, Словенія, Угорщина, Словаччина, Україна), панєвропейський № 7 Дунайський (Австрія, Угорщина, Югославія, Болгарія, Румунія, Молдова, Україна); панєвропейський № 9 (Фінляндія, Росія, Україна, Білорусь, Молдова, Румунія, Греція).

Україна $є$ активним учасником діяльності програми ТРАСЕКА, метою якої є розвиток транспортного сполучення з Свропи в країни Центральної Азії через Чорне море, Кавказ і Каспійське море. 3 технологічної точки зору програма орієнтується на перевезення вантажу за єдиним для всього маршруту транспортним документом при використанні різних видів транспорту. Передбачається, що реалізація програми ТРАСЕКА сприятиме інтеграції між країнами Європейського союзу i країнами-партнерами програми i більш ефективному розподілу ресурсів між країнами Заходу і Сходу.

Сьогодні міжнародний транспортний коридор ТРАСЕКА офіційно визнаний провідними міжнародними організаціями одним 3 природних транзитних мостів, що з'єднують Європу 3 Азією, так званий відроджений Шовковий Шлях. Коридор бере свій початок в країнах Східної Європи (Болгарія, Молдова, Румунія, Україна), і також перетинає Туреччину. Далі маршрут пролягає через Чорне море до портів Поті і Батумі в Грузії, потім задіє транспортну мережу країн Південного Кавказу а також Ісламської Республіки Іран, використовуючи наземне сполучення 3 цим регіоном з Туреччини. 3 Азербайджану за допомогою каспійських поромних переправ (БакуТуркменбаші, Баку-Актау) маршрут ТРАСЕКА виходить на залізничні мережі держав Центральної Азії Туркменістану і Казахстану, транспортні мережі яких пов'язані з напрямками в Узбекистані, Киргизстані, Таджикистані і досягають кордонів з Китаєм і Афганістаном, тоді як 3 Іраном країни Центральної Азії мають як сухопутне, так і морське сполучення.

Розвиток нового транспортного коридору сприяло формуванню ефективного транспортного потенціалу, що дозволяє забезпечувати всі зростаючі вантажопотоки 3 Азіатсько-Тихоокеанського регіону в Європу. Це також дозволяє створювати і розширювати ринки країн ТРАСЕКА і поступово інтегруватися в Транс'європейські транспортні мережі.

Результати досліджень. Теоретично може розраховувати на потоки міжнародних вантажів з понад 260 млн тон, які становлять обсяги торгівлі між Китаєм і ЄС. Однак існує ряд перешкод, які роблять малоймовірним масштабне входження України в проект Нового шовкового шляху. По-перше, Україна не є членом ЄС, на відміну від Болгарії та Румунії, що ускладнює проходження митного кордону. Україна також має непрозорий і тривалий механізм оформлення митних вантажів, що на фоні високої вартості суднозаходів та відсутності достатньої кількості якісних доріг для автосполучення з СС, робить ії менш привабливою в порівнянні з іншими країнами ЄС [2, 3].

На початку лютого 2016 р. міністерством інфраструктури України був протестований Транскаспійський залізничний маршрут, якій починався 3 українського порту Іллічівськ $\mathrm{i}$ закінчувався на китайському кордоні. За інформацією міністерства вже з 2017 р. контейнерний поїзд в Китай почав роботу в бізнес-режимі в рамках альтернативного коридору "Шовковий вітер".

Україна з чорноморськими портами може стати одним 3 ключових ланок китайського проекту. Збільшення потоку товарів щодо Транскаспійського маршруту здешевить собівартість перевезень. До транзитних транспортних маршрутів може підключитися також контрейлерний поїзд "Вікінг", який курсує з 2003 року і з'єднує порти Одеса та Іллічівськ через Мінськ 3 литовським портом Клайпеда. Прес-служба українського уряду на початку лютого 2016 р. 
повідомляла, що з Литвою був підписаний меморандум про об'єднання проекту "Шовковий вітер" через Україну в Китай з проектом "Вікінг".

Поїзд комбінованого транспорту «Вікінг» $є$ спільним проектом залізниць Литви, Білорусі, України, портів Клайпеда, Іллічівськ і Одеса. 3 огляду на перспективність проекту «Вікінг» в області залучення додаткових обсягів перевезень вантажів, його географія поступово розширюється:

2012 рік - ЕООО "БДЖ - Вантажні перевезення" (Болгарія);

2013 рік - ДП «Залізниця Молдови» (Молдова);

2014 року - АТ «ЧФР Марфа» (Румунія);

2015 - АТ «Грузинська залізниця» (Грузія);

2016 - ЗАТ «Азербайджанські залізниці» (Азербайджан).

На сьогоднішній день маршрут проходить через Болгарію, Румунію, Молдову, Азербайджан, Грузію, Україну, Білорусь і Литву і з'єднує ланцюг морських контейнерних і контрейлерних ліній Балтійського регіону з аналогічною системою Чорного і Каспійського морів.

Співпраця учасників проекту передбачає створення платформи для проведення переговорного процесу 3 Міністерствами транспорту, залізничними, митними та прикордонними адміністраціями (Республіки Білорусь, Литви, Республіки Туреччина, Україна, Грузії, Вірменії, Сирії, Болгарії, Греції) щодо спрощення здійснення митного контролю та митного оформлення вантажів, які переміщуються через митні кордони країн-учасниць процесу перевезень поїздом «Вікінг».

Ще однією 3 цілей проекту $\epsilon$ залучення вантажів для перевезення залізничним транспортом в напрямку Європа-Кавказ-Азія по коридору ТРАСЕКА, а також перевезення вантажів з Туреччини і країн Близького Сходу в північні країни Європи і в зворотному напрямку.

Включення транспортної системи України i Туркменістану у єдину систему транспортного сполучення та транзиту, що охоплює простори континентальної Євразії з виходом на морські термінали Чорноморського і Балтійського регіонів, Південної і Південно-Східної Азії, а також Близького Сходу потребує удосконалення транспортних систем обох країн.

Стратегічним завданням науково-технічної політики в області транспортної галузі України є вихід на світовий рівень за технічними параметрами та якістю послуг, що реалізуються транспортом. Оптимізація міжнародних перевезень вантажів по різним комбінаціям спільної роботи всіх видів транспорту України та Західної Європи є головним напрямом підвищення конкурентоспроможності країни на міжнародному ринку.

В Національному транспортному університеті проводяться наукові дослідження 3 проблеми створення прогресивних технологій організації міжнародних мультимодальних вантажних перевезень з використанням сучасних інформаційних та транспортних технологій [4].

Розроблено модель комплексних перевезень у транспортній системі, яка дає можливість системно підійти до задачі оптимізації міжнародних транспортних перевезень неоднорідних вантажів за комбінованою схемою використання різних видів транспорту (автомобільного, водного і залізничного) з урахуванням усього спектра обмежень, що існують у системах подібного роду [4].

База даних транспортної інфраструктури створеної моделі включає масив з 794 крупних транспортних вузлів, що лежать на автомагістралях міжнародного значення, масив 3566 залізничних станцій і масив з 119 морських портів України та Західної Свропи.

Виходячи з того, що перевезення між населеними пунктами (н/п) можуть здійснюватися або 3 використанням одного виду транспорту, або декількох, маємо наступні варіанти перевезення вантажу:

1) перевезення автомобільним транспортом здійснюються від н/п постачальника будьякого типу до н/п спожсивача також будь-якого типу, тобто за наступною схемою:

$$
\begin{aligned}
& \mu / n 1 \div 4 \text { muny } \rightarrow \text { h } / n 1 \div 4 \text { muny і дорівнює } \\
& K_{1}=2 ! \cdot C_{M}^{2}+\ldots+(M-1) ! C_{M}^{M-1} \text { комбінацій перевезень; }
\end{aligned}
$$

Примітка: знак $\rightarrow$ означає процес перевезення;

2) перевезення залізничним транспортом припускають наявність у н/п постачальника й споживача вантажу залізничною станцією (3/c) і здійснюються за наступною схемою:

$$
\text { H/n 2, } 4 \text { muny } \rightarrow \text { h/n 2, } 4 \text { muny і дорівнює }
$$

$$
K_{2}=2 ! C_{M_{2}+M_{4}}^{2}+3 ! \cdot C_{M_{2}+M_{4}}^{3}+\ldots+\left(M_{2}+M_{4}-1\right) ! C_{M_{2}+M_{4}}^{M_{2}+M_{4}-1} \text { комбінацій перевезень; }
$$


3) перевезення водним транспортом припускають наявність у н/п постачальника й споживача вантажу водним пунктом (в/п) і здійснюються за наступною схемою:

$\mu / n$ 3,4 muny $\rightarrow \mu / n$ 3,4 muпy і дорівнюе

$$
K_{3}=2 ! C_{M_{3}+M_{4}}^{2}+3 ! C_{M_{3}+M_{4}}^{3}+\ldots+\left(M_{3}+M_{4}-1\right) ! C_{M_{3}+M_{4}}^{M_{3}+M_{4}-1} \text { комбінацій перевезень; }
$$

4) перевезення спочатку автомобільним, а потім водним видами транспорту припускають переміщення вантажу спочатку від н/п постачальника будь-якого типу автомобільним транспортом до найближчого до нього в/п і потім водним транспортом до н/п споживача вантажів, що має в/п і здійснюються за наступною схемою:

$\mu / n 1 \div 4$ muny $\rightarrow H / n$ 3,4 muny $\rightarrow H / n$ 3,4 muny і дорівнює

$$
K_{4}=K_{1} \cdot K_{3} \text { комбінацій перевезень; }
$$

5) перевезення спочатку водним, а потім автомобільним видами транспорту припускають переміщення вантажу спочатку від н/п постачальника, що має в/п водним транспортом до найближчого до н/п споживача вантажу в/п і потім автомобільним транспортом до н/п споживача вантажу будь-якого типу й здійснюються за наступною схемою:

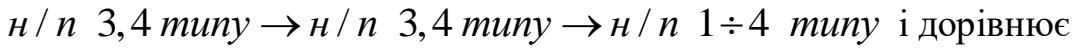

$$
K_{5}=K_{3} \cdot K_{1} \text { комбінацій перевезень; }
$$

6) перевезення спочатку автомобільним, після водним, а потім знову автомобільним видами транспорту припускають переміщення вантажу автомобільним транспортом спочатку від н/п постачальника будь-якого типу до найближчого до нього в/п, після водним транспортом до найближчого до н/п споживача вантажу в/п і потім автомобільним транспортом до н/п споживача вантажу будь-якого типу й здійснюються за наступною схемою:

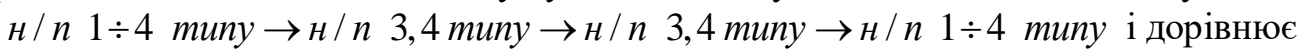

$$
K_{6}=K_{1} \cdot K_{3} \cdot K_{1} \text { комбінацій перевезень; }
$$

7) перевезення спочатку автомобільним, а потім залізничним видами транспорту припускають переміщення вантажу спочатку від н/п постачальника будь-якого типу автомобільним транспортом до найближчої до нього 3/с і потім залізничним транспортом до н/п споживача вантажів, що має з/с і здійснюються за наступною схемою:

$H / n 1 \div 4$ mипу $\rightarrow H / n 2,4$ muny $\rightarrow H / n$ 2,4 muпy і дорівнює

$$
K_{7}=K_{1} \cdot K_{2} \text { комбінацій перевезень; }
$$

8) перевезення спочатку залізничним, а потім автомобільним видами транспорту припускають переміщення вантажу спочатку від н/п постачальника, що має з/с залізничним транспортом до найближчої до н/п споживача вантажу з/с і потім автомобільним транспортом до н/п споживача вантажу будь-якого типу й здійснюються за наступною схемою:

$H / n$ 2,4 muny $\rightarrow H / n \quad 2,4$ muny $\rightarrow H / n 1 \div 4$ mипу і дорівнює

$$
K_{8}=K_{2} \cdot K_{1} \text { комбінацій перевезень; }
$$

9) перевезення спочатку автомобільним, після залізничним, а потім знову автомобільним видами транспорту припускають переміщення вантажу автомобільним транспортом спочатку від н/п постачальника будь-якого типу до найближчої до нього з/с, після залізничним транспортом до найближчої до н/п споживача вантажу з/с і потім автомобільним транспортом до н/п споживача вантажу будь-якого типу й здійснюються за наступною схемою:

$H / n \quad 1 \div 4$ muny $\rightarrow H / n \quad 2,4$ muny $\rightarrow H / n$ 2,4 muпy $\rightarrow H / n \quad 1 \div 4$ mипу і дорівнює

$$
K_{9}=K_{1} \cdot K_{2} \cdot K_{1} \text { комбінацій перевезень. }
$$
становити:

Виходячи з вище викладеного загальна кількість комбінацій перевезення вантажів буде

$$
K=\sum_{i=1}^{9} K_{i} \quad(i=\overline{1,9)}
$$

Висновки. Програмний комплекс з оптимізації міжнародних вантажних перевезень на транспортній системі України та Західної Свропи, якій створений на основі моделі управління мультимодальними вантажними перевезеннями у міжнародному сполученні, ураховує пропускні 
здатності транспортних вузлів і комунікацій транспортних систем, а також може вирішувати транспортні задачі за умови незбалансованості обсягів перевезення неоднорідних вантажів.

Розроблена модель комплексних перевезень у транспортній системі України та Західної Європи може бути розвинута до вирішення задачі оптимізації міжнародних транспортних перевезень вантажів за комбінованою схемою використання різних видів транспорту для Великого Шовкового шляху і Морського Шовкового шляху.

\section{ЛIТЕРАТУРА}

1. Офіційній сайт Держкомстату України [Електронний ресурс] - Режим доступу: - // www.ukrstat.gov.ua.

2. Відновлення транзитного потенціалу в контексті підвищення конкурентоспроможності України на міжнародному ринку транспортних послуг: аналіт. записка. [Електронний ресурс]/ К.М. Михайличенко, С.В. Бєлашов. - Режим доступу: - http://www.niss.gov.ua/articles/1844/.

3. Прокудін Г.С. Аналіз і шляхи реформування транспортної галузі України / Г.С. Прокудін, О.А. Чупайленко, І.О. Ремех, К.О. Майданик, Ю.В. Пилипенко // Транспортні системи і технології. Київ: ДЕТУТ, 2017. - С. 244-254.

4. Prokudin G. Improvement of the methods for determining optimal characteristics of transportation networks / G. Prokudin, O. Chupaylenko, O. Dudnik, A. Dudnik, D. Omarov // Eastern-European Journal of Enterprise Technologies. 2016. N. 6/3 (84). P. 54-61. DOI:10.15587/1729-4061.016.85211). 